\title{
Seasonal Changes in the Water Content and Level in the Bank Vole against the Background of Other Gross Body Components
}

\author{
Anna FEDYK
}

Fedyk A., 1977: Seasonal changes in the water content and level in the bank vole against the background of other gross body components. Acta theriol., 22, 26: 355-363 [With 4 Tables].

The amounts and proportions of water, fat and mineral substances have been examined in summer and winter populations of wild bank voles, Clethrionomys glareolus (S c h r e be r, 1780). The bank voles of the winter sample were characterized by smaller body weights than were the individuals of the summer sample. The differences in the absolute amounts of body components are, except fat, proportional to the differences in body weight. The data obtained deny the existence of seasonal changes in the hydration of the bank vole organism in the sense of its winter dehydration and spring rehydration.

[Mammals Res. Inst., Polish Acad. Sci., 17-230 Białowieża, Poland]

\section{INTRODUCTION}

Many morphological and physiological data concerning seasonal changes in small mammals of the temperate zone have been accumulated within the last two decades. Seasonal fluctuations in the basic body components of these animals have also been recorded, especially changes in fatness (for extensive references see Schreiber \& Johnson, 1975). As regards other body components, only the regularities and succesion of changes in the amounts and proportions of water, protein and mineral substances in the postnatal development of several rodent species have been studied more extensivelly (see F e dy k, 1974a, 1974b for a review of literature). The data on seasonal changes in water content and level in an organism are controversial. There is evidence that the amount and proportion of water in the organism of rodents and insectivores are lower in winter than in summer ( $\mathrm{J}$ a m e s o n \& M e a d, 1964; Gór ecki, 1965; M y r cha, 1969; Fleharty, Krause \& Stinnet, 1973; S a wick a-K a pusta, 1974; Schreiber \& Johnson, 1975). There are also data which indicate that the changes in the hydration of animals are associated with their age and physiological conditions (e.g. lactation) varying with seasons (E v a n s, 1973; F e d y k, 1974b). 
The purpose of the present study is to investigate to what extent the hydration of organism depends on seasons and in what measure these seasonal changes differ from the level characteristic of the given age group.

\section{MATERIAL AND METHOD}

The subject of this study was the bank vole, Clethrionomys glareolus ( $\mathrm{S} \mathrm{c} \mathrm{h} \mathrm{re-}$ ber, 1780), in which the changes in body components during the postnatal development had already been studied in detail ( $\mathrm{F}$ e dy k, 1974a, b; S a w i c k a-K apus t a, 1974).

Bank voles were trapped in the same study area twice, from January 31 to February 6 and from August 14 to August 25, in the year 1973; members of the winter and summer population were thus obtained.

On the day of trapping the animals were weighed, their alimentary canals and mandibles were excised, and they were weighed again. Mandibles were taken for further age determination by method described by P u cek \& $\mathrm{Zejda}$ (1968). The amounts of water, protein, fat and mineral substances were determined in the remainders by the methods described earlier (Fedyk, 1974a). Some of the animals, weighed and killed in ether anaesthesie, were skinned and the pelt was weighed. The liver, kidneys, heart and brain were also weighed after they had been removed from the body. The pelt and organs were dried to a constant weight, the amount of water being thus obtained. The gross body components were examined in total of 142 bank voles.

Standard statistical procedures have been applied to obtain absolute data and the significance of differences between the averages for the summer and winter animals has been determined by Student's $t$ test.

\section{RESULTS}

The age structures of the bank voles representing the winter and summer samples are different (Table 1). In the winter sample as many as $78 \%$ of the specimens are $6-10$ months of age, i.e. they are animals from spring and summer litters, whereas in the summer sample 2-6month old specimens, also born in the spring, prevail. Thus, most of the specimens of the winter and summer populations trapped are bank voles of the spring generation. However, the average age of the winter voles is about 10 months and the average age of those trapped in the summer about 5 months. A similar age structure was characteristic of the bank voles from which the internal organs were removed.

$\mathrm{B}$ asic body components. As regards body composition the bank voles of the winter population differ significantly $(P<0.001)$ from those of the summer population (cf. Table 2). The bank voles trapped in the winter were characterized by the lower mean values of all the parameters examined than those of the animal caught in the summer with the only exception of fat, which in the wintering voles came to $132.8 \%$ 
of the amount found in the voles collected in the summer. The summer voles outweighed the wintering ones by $1.96 \mathrm{~g}$. The former also exceeded the latter by $2.12 \mathrm{~g}$ in the weight of eviscerated bodies. The difference between them averaged $1.84 \mathrm{~g}$ in the amount of water in organism, $0.59 \mathrm{~g}$ in the amount of protein and $0.10 \mathrm{~g}$ in that of mineral substances.

It might be inferred from these data that the wintering bank voles are worse hydrated than those living in summer $(3.7 \%$ difference - Table 3$)$.

Table 1

Numbers of Clethrionomys glareolus analysed with respect

to basic body components in particular are groups and relative to trapping season.

\begin{tabular}{cccc}
\hline Age classes & Age in months & Winter & Summer \\
\hline I & -2 & - & 1 \\
II & -4 & - & 37 \\
III & -6 & 2 & 12 \\
IV & -8 & 12 & 2 \\
V & -10 & 27 & - \\
VI & -12 & 8 & - \\
VII & -14 & 1 & 2 \\
\hline
\end{tabular}

Table 2

Basic body components of C. glareolus trapped in winter and in summer. Mean absolute value \pm standard deviations are given; coefficients of variation are given in brackets.

\begin{tabular}{lrr}
\hline \multicolumn{1}{c}{ Items } & Winter & \multicolumn{1}{c}{ Summer } \\
\hline Body weight, g & $14.564 \pm 1.549(10.6)$ & $16.528 \pm 3.055$ \\
Eviscerated body & $(8.5)$ \\
Water & $10.132 \pm .910(19.0)$ & $12.257 \pm 2.455(20.0)$ \\
Dry mass & $6.626 \pm .556(8.4)$ & $8.472 \pm 1.745(20.6)$ \\
Fat & $3.500 \pm .389(11.1)$ & $3.784 \pm .835(21.8)$ \\
Protein & $.965 \pm .250(25.9)$ & $.587 \pm .278(47.3)$ \\
Ash & $2.108 \pm .178(8.5)$ & $2.701 \pm .552(20.4)$ \\
FFB & $.395 \pm .060(15.2)$ & $.497 \pm .117(23.6)$ \\
& $9.146 \pm .907(9.9)$ & $11.657 \pm 2.392(20.5)$ \\
\hline
\end{tabular}

The protein content and that of mineral substances are also lower in them, but the share of fat is proportionally higher, namely, by nearly $4.6 \%$. However, if the percentage share in the fat-free body $(F F B)$ (Table 3, middle part) has been assumed as the basis of reference, the percentage shares of water, protein and mineral substances will be alike (the differences are of the order of a tenth part of a percent). Since in literature we often meet with the calculations of gross body composition $(G B C)$ in relation to dry matter, they are also presented in the table mentioned above. Thus, if in relation of fresh matter the differences 
in the proportions of protein in the organism of the bank voles under comparison come to $1.3 \%$, in relation to dry matter they are nearly ten times as great. It is also possible to compute the amount of water in relation to the dry matter of the organism. The index thus obtained is $180 \%$ for bank voles trapped in the winter and $223 \%$ for those occurring in the summer, the difference being as high as $34 \%$ in favour of the summer animals.

Some interesting data have been obtained by comparing the fresh weights of the organs selected with the weights of their dry matter (Table 4). The internal organs of the studied groups of animals differ in weight, but then proportionally to the differences in body weight, which is indicated by the relative weights of these organs. (Small differences

Table 3

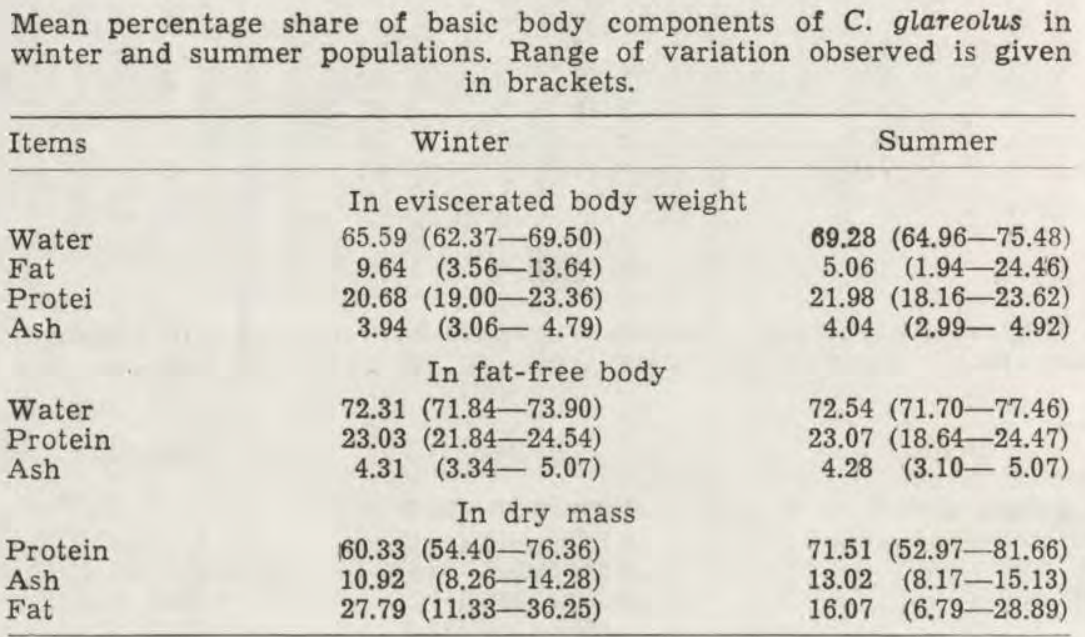

in the relative weights compared may be due to the basis of comparison, which in this case is the weight of body with the alimentary canal filled with food to a various degree.) The dry matter differs significantly between the groups compared only in the case of kidneys, the fresh weight of which is considerably higher in the bank voles living in the summer. It is difficult to form an opinion on the significance of the differences in the percentage content of water in the organs studied, since they are intensely supplied with blood.

On the other hand, distinct differences are observed in the weight of pelt, which in the wintering bank voles is one-sixth of its weight in the summer voles (Table 4) and this is reflected by its relative weight. Any- 
way, in dry matter the differences amount to only about $260 \%$. Hence the conclusion that the pelts differ significantly in water content.

\section{DISCUSSION}

Seasonal differences in water content have been demonstrated in ten species inhabiting different geographical regions and differentiated in respect of their ways of living (Górecki, 1965; Fleharty, et al., 1973; S a wicka-Kapusta, 1974; Schreiber \& Johnson, 1975). In these rodents the water content was compared with the body weight and sometimes with the contents removed from the stomachs. A similar significant winter decrease in the water concentration in the whole

Table 4

Weights of selected internal organs and skin of C. glareolus trapped in winter (W) and in summer (S).

\begin{tabular}{lrrrrr}
\hline \multicolumn{1}{c}{ Items } & & Wet weight, $g$ & $\begin{array}{l}\text { Relative } \\
\text { weight }\end{array}$ & Dry weight, g & Water, \% \\
\hline Whole animal & W: & $14.441 \pm 2.14$ & & & \\
Liver & S: & $18.086 \pm 2.43$ & & & \\
& W: & $1.023 \pm .18$ & 6.93 & $.366 \pm .058$ & 72.74 \\
Kidneys & S: & $1.224 \pm .30$ & 6.82 & $.347 \pm .080$ & 71.63 \\
& W: & $.186 \pm .04$ & 1.37 & $.054 \pm .001$ & 72.62 \\
Brain & S: & $.296 \pm .03$ & 1.63 & $.072 \pm .001$ & 75.81 \\
& W: & $.481 \pm .04$ & 3.18 & $.110 \pm .001$ & 77.17 \\
Heart & S: & $.529 \pm .06$ & 3.03 & $.115 \pm .014$ & 78.35 \\
Skin & W: & $.121 \pm .02$ & 0.84 & $.033 \pm .001$ & 74.63 \\
& S: & $.142 \pm .02$ & 0.79 & $.035 \pm .001$ & 75.54 \\
& W: & $1.629 \pm .182$ & 12.66 & $.902 \pm .132$ & 45.31 \\
& S: & $10.971 \pm 1.800$ & 60.51 & $3.222 \pm 1.223$ & 64.88 \\
\hline
\end{tabular}

organism was noted in some Soricidae (M y r ha, 1969) and even in the cerebral tissue of Sorex araneus (P u c e k, 1965).

However, in investigating the $G B C$ of six geographical breeds of $\mathrm{Pe}$ romyscus, acclimated to laboratory conditions, H a yw a r d (1965) did not find any significant changes in the proportions of water (and protein) in the fat-free body, whereas a summer population of wild Peromyscus showed a lower water level than that in the wintering specimens, accompanied by a simultaneous increase in the protein level. The author gives no opinions on the significance of these changes but only supposes that they may have been caused by differences in the quality of pelt.

It has also been found that the hibernating bats have a higher percentage water content in the FFB $\left(69.5^{\circ} \%\right)$ than have the bats active at that time, (i.e. $68 \% \mathrm{~K}$ a $11 \mathrm{e} \mathrm{n}, 1964$ ). However, that author did not study the water content in bats in the season of their natural activity. Instead, it 
has been observed in other hibernating animals that the autumn decrease in the body weight was accompanied by a fall in the water index (water index $=$ water weight/weight of defatted dry matter $\times 100)(\mathrm{J}$ a m e s o n $\& \mathrm{M}$ e a d, 1964). These last authors suggest that the autumn decrease in the water content of organism is perhaps important to hibernating animals, but no investigation has been carried out in the hibernation season. On the other hand, it is well known that the water content in organism is extremely stable in birds, even during long flights, when their total body weight decreases ( $\mathrm{R}$ o g e r s \& O d u m, 1964). Investigating, seasonal changes in the water content of Microtus agrestis, Evan s (1973) found significant changes in the absolute amounts of water in organism, which were however accompanied by changes in other components. The changes in the water content of these animals were rather connected with their age and physiological conditions than with the season.

Anyway, the objective of this discussion is not to quote data supporting or denying the results obtained now. In the light of the results obtained in the present work the existence of seasonal variation in the water content of the organism of rodents still remains an open problem and so it will until a study has been carried out on one and the same specimen in different seasons of the year (using supravital methods). Admittedly, fat is an unhydrous compound and therefore the whole amount of water of an organism is contained in its fatless mass. No seasonal changes in water content have been found in this fraction of the organism of C. glareolus. It was also observed that the mean body weight of the wintering voles was smaller than that of the summer animals, which is a regularity in the case of most rodents of the moderate zone. This is responsible for the lower absolute amounts of protein, water and mineral substances falling to one wintering bank vole in comparison with the summer individual. Analysed in relation to the FFB, these amounts are however proportionally smaller.

It cannot be determined on the basis of the conversions presented in Table 3 that the winter bank voles have a lower water content than the summer ones and that the water content in their organism is dependent on the season of the year. Neither can it be inferred that the bank voles, whose "chemical « characteristics are given in Table 2, gained the here calculated and statistically significant amounts of protein, water and mineral substances in the summer in comparison with the values obtained for the winter specimens. This would not be an inference concerning the biological phenomenon examined, but only a statistical inference, for in each case we examine different samples of specimens of a population varying in its age structure and perhaps characterized by different 
features as regards their GBC (cp. F e dy k, 1974a, b and S a w ickaK a pusta, 1974).

The age composition of the bank voles under study, presented in Table 1, suggests that the animals of the groups compared belonged for the most part to the spring generations of two consecutive years. They should supposedly be marked by a similar rate of development. However, in the light of ecological data available for this species the predominance of the spring-generation bank voles in a randomized sample of the winter population is a striking fact, since normally they should constitute a slight percentage of the specimens (P u cek, Ryszkowski \& $\mathrm{Zejda}, 1969 / 70 ; \mathrm{Zejda}, 1971)$. The method for age determination adopted in this study is undoubtedly charged with a certain error (for details see $\mathrm{L}$ ow e, 1971; $\mathrm{Zejda}$, 1971). Assuming the existence of error in the age determined, the smaller weight of the wintering voles than the summer ones may be associated with the different rate of development typical of the autumn generation, which should prevail in the winter sample. The body weight is besides influenced by the state of the reproductive organs, which in the seasons being compared differs diametrically. This is presumably the only way of consistent explanation of the so-called "negative growth" of bank voles in winter ( $\mathrm{H}$ a itlinge r, 1965).

It may be stated for a certainty that the evolutionary success of mammals is due to both their capacity for adaptive modification of behaviour and their well-developed capacity for homeostasis, carried into effect by changes of a physiological nature. On the other hand, one of the fundamental characters of living matter is the precise purposefulness of its structures, forms and function. At the same time, the thus expressed purposefulness should be understood as a contemporaneously observed effect of the long-ago or still undiscovered causes. Assuming this point of view, one finds it hard to imagine the ways in which the seasonal loss of water, conjectured for years ( $\mathrm{Dehne}$, 1949), proceeds in the organism of small mammals. Perhaps we should attempt to calculate the energy cost of such a dehydration and rehydration of organism and to consider their environmental necessity, whether in the case of dehydration the osmotic pressure changes and what consequencies it has.

Special attention should be paid to the fact that the amount of water in healthy adult mammals relative to the FFB fluctuates within narrow limits $(72-74 \%)$. It seems that the amount of water of an organism, obtained by the substraction of extracellular fluids from its total amount of water, is indispensable for the optimum hydration of biomolecules and for the cell to function normally. 


\section{REFERENCES}

1. Dehnel A., 1949: Badania nad rodzajem Sorex L. Annls Univ. M. Curie-Skłodowska, sect. C, 4: 17-97.

2. Evans D. M., 1973: Seasonal variations in body composition and nutrition of the vole Microtus agrestis. J. Anim. Ecol., 43: 1-18.

3. Fedyk A., 1974 a: Gross body composition in the postnatal development of the bank vole. I. Growth under laboratory conditions. Acta theriol., 19: $381-401$.

4. Fedyk A., 1974b: Gross body composition in the postnatal development of the bank vole. II. Differentiation of seasonal generations. Acta theriol., 19: $403-427$.

5. Fleharty E. D., Krause M. E. \& Stinnet D. P., 1973: Body composition, energy content and lipid cycles of four species of rodents. J. Mammal., 54: $426-438$.

6. Górecki A., 1965: Energy values of the small mammals. Acta theriol., 10: $333-352$.

7. H a y ward J. S., 1965: The gross body composition of six geographic races of Peromyscus. Can. J. Zool., 43: 297-308.

8. Haitlinger R., 1965: Morphological analysis of the Wrocław population of Clethionomys glareolus (S c hreber, 1780). Acta theriol., 10: 243-272.

9. Jameson E. W., Jr. \& M e a d R. A., 1964: Seasonal changes in body fat, water and basic weight in Citellus lateralis, Eutamias speciosus, and E. amoenus. J. Mammal., 45: 359-365.

10. Kallen F. C., 1964: Some aspects of water balance in the hibernating bat. Ann. Acad. Sci. Fenn., ser. A IV, Biol., 71: 259-265.

11. My rcha A., 1969: Seasonal changes in caloric value, body water and fat in some shrews. Acta theriol., 14: 211-227.

12. Pucek M., 1965: Water contents and seasonal changes of the brain weight in shrews. Acta theriol., 10: $353-367$.

13. Pucek Z. \& $\mathrm{Zejda}$ J., 1968: Technique for determination age the red-backed vole, Clethrionomys glareolus (S chreiber, 1780). Small Mamm. Newslett., 2: $51-60$.

14. Pucek Z., Ryszkowski L. \& Zejda J., 1969/70: Estimation of average length of life in bank vole, Clethionomys glareolus ( $\mathrm{S} \mathrm{ch} \mathrm{reber,} \mathrm{1780).} \mathrm{[In:}$ »Energy flow through small mammal populations«, Eds.: Petrusewicz K. \& Ryszkowski L.]. Państw. Wyd. Nauk.: 187-201. Warszawa.

15. Low e V. P. W., 1971: Root development of molar teeth in bank vole (Clethrionomys glareolus). J. Anim. Ecol., 40: 49-61.

16. Rogers D. T. \& Odum E. P., 1964: The effect of age, sex, and level of lipid deposition on major body composition in some wood warblers. Auk, 81: 505513.

17. Sawicka-Kapusta K., 1974: Changes in the gross body composition and energy value of the bank vole during their postnatal development. Acta theriol., 19: 27-54.

18. Schreiber R. K. \& Johnson D. R., 1975: Seasonal changes in body composition and caloric content of Great Basin rodents. Acta theriol., 20: $343-364$.

19. $\mathrm{Zejda}$ J., 1971: Differential growth of three cohorts of the bank vole, Clethrionomys glareolus, Schreb., 1780, Zool. Listy, 20: 229-245.

Accepted, March 28, 1977. 
Anna FEDYK

\section{SEZONOWE ZMIANY ZAWARTOSCI I POZIOMU WODY U NORNICY RUDEJ NA TLE INNYCH PODSTAWOWYCH SKEADNIKOW CIAEA}

\section{Streszczenie}

Zbadano ilości i proporcje wody, tłuszczu i substancji mineralnych u dzikich Clethionomys glareolus (S chreber, 1780) odłowionych $\mathrm{z}$ tej samej populacji w zimie i latem. Skład wiekowy nornic odłowionych zimą jest inny niż zwierząt odłowionych latem (Tabela 1). Sredni wiek nornic zimujących wynosi około 10 miesięcy, podczas gdy odłowionych latem - 5 miesięcy. Większość nornic obydwu prób sezonowych należy do generacji wiosennej. Pod względem badanych parametrów nornice zimujące różnią się istotnie od nornic bytujących latem (Tabela 2). Nornice zimujące mają średnio niższe wszystkie wartości parametrów niż nornice odłowione w lecie. Wyjątek stanowi jedynie tłuszcz, który u nornic zimujących stanowił $132.8 \%$ ilości stwierdzonej u nornic latem. Na podstawie procentowej zawartości wody w organizmie nornic, można przypuszczać, że osobniki zimujące są mniej uwodnione od osobników żyjących w lecie, jeśli za podstawę porównań przyjmiemy ciężar ciała (Tabela 3). Jeśli podstawą odniesień jest beztluszczowa masa ciała (FFB) - różnice w uwodnieniu zanikają. Można je jednak uwielokrotnić odnosząc zawartość wody w stosunku do suchej masy organizmu. Proporcjonalnie do mniejszych rozmiarów ciała zwierząt zimujących, mniejsze są u nich ciężary narządów wewnętrznych (Tabela 4). Jedynie skóra zwierząt bytujących latem jest sześciokrotnie cięższa niż skóra nornic zimujących i istotnie różni się uwodnieniem. Uzyskane obecnie dane nie podtrzymują rozpowszechnionych $w$ literaturze wniosków odnośnie sezonowych zmian w uwodnieniu organizmu gryzoni. Faktem jest, że mniejszemu ciężarowi nornic zimujących towarzyszą proporcjonalnie mniejsze ilości składników podstawowych, a więc i wody, w beztłuszczowej masie ciała - w porównaniu z nornicami bytującymi latem. 